DOI https://doi.org/10.18551/rjoas.2018-09.12

\title{
THE EFFECT OF COMPANY FINANCIAL PERFORMANCE AND MACROECONOMIC VARIABLES ON STOCK RETURNS IN PROPERTY AND REAL ESTATE SECTORS IN INDONESIA STOCK EXCHANGE
}

\author{
Utama A.M.*, Wiksuana I G.B. \\ Postgraduate Program, University of Udayana, Bali, Indonesia \\ *E-mail: angelinemelissa@hotmail.com
}

\begin{abstract}
This study aims to determine the effect of company financial performance and macroeconomic variable on stock return of the Property and Real Estate companies listed on Indonesia Stock Exchange. There are five variables tested: Debt to Equity Ratio, Price to Book Value, Net Profit Margin, and Inflation and Interest Rate. The population of this study is sector of property and Real Estate listed on Indonesia Stock Exchange period 2014-2017. The numbers of samples are 26 companies. This study uses Multiple Linear Regression analysis and purposive sampling method. The results of this study found that Debt to Equity Ratio, Price to Book Value, Net Profit Margin, Inflation, and Interest Rate have a significant influence on stock return. Based on partial testing ( $t$ test) found that the Price to Book Value and Interest Rate have a positive and significant effect on stock return, while Debt to Equity Ratio, Net Profit Margin, and inflation have no significant effect on stock returns.
\end{abstract}

\section{KEY WORDS}

Stock return, debt to equity ratio, price to book value, net profit margin, inflation, interest rate.

The decision to choose an investment is not easy in determining it; careful consideration is needed by prospective investors from various points of view. Considerations can be made by conducting fundamental analysis and technical analysis. According to Jones (2014: 348) the stock assessment process consists of three stages, namely economic analysis, industrial analysis, and company analysis. Economic analysis (macro) is an analysis of external and macro factors in the form of events that occur outside the company and affect all companies so that they cannot be controlled by the company. Industry analysis aims to determine which industries are profitable and which are not good prospects. Company analysis aims to determine any company in the chosen industry that has good prospects.

Stock analysis provides an illustration of whether the selected stock will provide a level of profit that is in accordance with the expected level of return or vice versa. Shares known as "high risk-high return" characteristics have a high risk but also provide a high profit opportunity. Stocks allow investors to get a large amount of return or profit (capital gain) for a fairly short period of time. The volatility of stock prices can affect investors experiencing large losses in a short time, as well as not getting dividends and experiencing losses (capital loss). There are various alternative stocks offered by the capital market for investors, namely stocks in: Agriculture sector, mining sector, basic industrial and chemical sector, miscellaneous industry sector, consumer goods industry sector, property and real estate sector, infrastructure, utilities \& transportation sector, financial sector, trade, services and investment sectors.

The Indonesia Stock Exchange Trading in the property and real estate sectors also still showed positive performance, however, the companies engaged in this sector also had a high sensitivity to changes in macroeconomic conditions which affected the trading of shares on the Indonesia Stock Exchange (written by T.G Diredja; Kompas, October 25, 2013).

This research will focus on economic analysis and company analysis because it will focus on financial and macroeconomic ratios that can affect stock returns in the sector. Financial ratios are one of the measuring tools in analyzing a company's financial condition (Kasmir, 2010). According to Sutrisno (2012) stock returns can be influenced by financial 
performance such as liquidity ratios, profitability ratios such as solvency ratios, and market ratios. Tandelilin (2010: 342) summarizes some of the macroeconomic factors that influence stock returns are inflation, interest rates, currency exchange rates, economic growth rates and so on.

The variables of the company's financial performance in this study are Debt to Equity Ratio (DER), Price to Book Value (PBV) and Net Profit Margin (NPM), these variables are examined because they still have a research gap and are able to describe the condition of a company in terms of profit produced by the company, seeing the company's ability to pay its debt, and the market share price. While the macroeconomic variables studied are inflation and interest rates because there is a research gap and the two macroeconomic variables are most sensitive to the reaction of stock prices and stock returns. The interest rate uses the BI Rate as a reference because it becomes a benchmark in determining the amount of interest on loans and savings.

\section{LITERATURE REVIEW}

Fundamental analysis is used by investors to determine which market price is lower than its intrinsic value (undervalued) so that it is worth buying and which stock market price is higher than its intrinsic value (overvalued) so that it is profitable to sell. Choosing investments requires consideration by conducting fundamental analysis and technical analysis. According to Jones (2014: 348) the analysis process of stock assessment consists of three stages, namely economic analysis, industrial analysis and company analysis to calculate the value of the company's shares.

Investors' stock valuation analysis usually performs a fundamental analysis top-down to assess the company's prospects. Beginning with a macroeconomic analysis that affects the performance of the entire company, then by conducting an industry analysis, and finally conducting an analysis of the companies that issue the securities concerned to assess whether the securities issued are beneficial or detrimental to investors.

Signaling theory suggests how companies provide signals to users of financial statements. This signal is in the form of information about what has been done by management to realize the wishes of the owner. Signal theory explains that companies have the incentive to provide financial report information to external parties because of information asymmetry between the company and external parties. External parties then assess the company as a function of different signaling mechanisms. The manager provides information on financial statements that the company implements conservatism accounting policies that produce higher quality profits because this principle prevents companies from exaggerating profits and helping users of financial statements by presenting profits and assets that are not overstated.

The rate of return (return) of shares is the level of profit that will be obtained by investors / investors because they have invested their shares. According Jogiyanto (2010) returns can be interpreted as the results obtained from investments. The results that will be obtained by investors are not only profits but also can suffer losses if investors are unable to understand the condition of the company properly. One way investors understand the condition of a company is a fundamental assessment where investors can see the financial condition whether the company is developing or not.

Returns can be realized returns (realized returns) or expected returns. Realization return is the return that has occurred which is calculated using historical data. Return can be measured by total return, relative return, cumulative return, and adjusted return. Realization of returns is very important because it is used as a measure of company performance and as a basis for calculating expected returns and risks in the future. While expectation returns is the return that is expected to be obtained by investors in the future. This return can be measured by the expected future value, the value of historical return, and the model of expected return.

According to Brigham and Houston (2013: 103) companies with low debt to equity will have a small risk of loss when the economic situation deteriorates, but when economic 
conditions improve, opportunities in earning a profit are also low. Conversely, companies with high leverage ratios do bear the risk of large losses when the economy is declining, but in good condition, the company has the opportunity to get big profits. Companies with high profits will be able to pay a higher dividend, so that in relation to the profit of one share that will rise due to higher debt levels, leverage can increase stock prices (Brigham and Houston, 2013: 24).

The higher the Price to Book Value (PBV) ratio of a company indicates the higher the investor's assessment of the company concerned, relative to the funds invested. With this PBV ratio, investors can find out how many times the market value of a stock has been valued from its book value and can give a picture of the potential price movements of a stock so that from this picture, indirectly the PBV ratio also affects stock prices. The high ratio of Price to Book Value (PBV) of a company shows that the higher the company is valued by investors. If a company is rated higher by the investor, the company's stock price will increase in the market, resulting in an increase in the company's stock return. This is what will further lead to positive sentiment among investors.

Net Profit Margin with this high ratio indicates the ability of a company to generate high profits at a certain level of sales, on the contrary if the ratio is low indicating sales that are too low for a certain level of costs, or costs that are too high for a certain level of sales, or a combination of both. A low ratio can indicate management inefficiencies. The greater the Net Profit Margin will give a positive signal to investors to invest their capital in the company in hopes of obtaining high returns, so that when NPM increases, it is offset by the increase in the company's stock returns. The greater the value of Net Profit Margin (NPM), the better the company's ability to obtain high profits.

The most widely used measure of inflation is Consumer Price Index. CPI changes from time to time show the price movements of the package of goods and services consumed by the public. The determination of goods and services is carried out on the basis of the Cost of Living Survey (SBH) carried out by the Central Statistics Agency (BPS). Inflation is a macroeconomic factor that is able to benefit and harm the company. Basically high inflation is not favored by capital market players because it will increase production costs and operational costs of the company. But on the other hands inflation will also increase the selling price of the company's products. (Andes et. Al, 2017).

Interest rate is the amount of interest paid per unit of time. In other words, people must pay for opportunities to borrow money. Indonesian interest rates are securities in recognition of short-term debt issued by Bank Indonesia with a discount system. The cost of borrowing money measured in Rupiah or Dollar per year for every Rupiah or Dollar borrowed is the Interest Rate. An increase in unreasonable interest rates will make it difficult for businesses to pay interest and liabilities, because high interest rates will add to the burden on the company so that it will directly reduce the company's profit.

Hypothesis:

$\mathrm{H} 1$ : debt to equity ratio has a negative and significant effect on stock returns;

$\mathrm{H} 2$ : price to book value has a positive and significant effect on stock returns;

H3: net profit margin has a positive and significant effect on stock returns;

$\mathrm{H} 4$ : inflation has a negative and significant effect on stock returns;

$\mathrm{H} 5$ : the interest rate has a negative and significant effect on stock returns.

\section{METHODS OF RESEARCH}

This study uses a quantitative approach and is designed to examine the causal relationship or influence between Debt to Equity Ratio (DER), Price to Book Value (PBV), Net Profit Margin (NPM), Inflation and Interest Rates on Stock Returns in Property Sector companies and Real Estate. The population of this study is all Property and Real Estate Sector companies listed on the Indonesia Stock Exchange in the 2014-2017 period totaling 44 companies. The sample in this study was taken by purposive sampling method, namely sampling based on subjective considerations of research tailored to the research objectives. The data analysis technique used in this study is to use Multiple Linear Regression and use 
combined data between cross section and time series (data panel). Multiple Linear Regression is a technique in determining the relationship between two or more independent variables with the dependent variable. Data processing will use Statistical Packages for the Social Sciences (SPSS) Version 22.

\section{RESULTS OF STUDY}

Multiple liner regression analysis in this study was used to determine whether there was influence of Debt to Equity Ratio (DER), Price to Book Value (PBV), Net Profit Margin (NPM), Inflation and Interest Rate on Stock Returns as stated below:

$$
Y=-0.170+0.011 \times 1+0.012 \times 2+0.023 \times 3+0.012 \times 4+0.023 \times 5+e
$$

Table 1 - Multiple Linear Regressions Testing Result

\begin{tabular}{|c|c|c|c|c|c|c|}
\hline \multirow{2}{*}{\multicolumn{2}{|c|}{ Model }} & \multicolumn{2}{|c|}{ Unstandardized Coefficients } & \multirow{2}{*}{$\begin{array}{l}\text { Standardized Coefficients } \\
\text { Beta }\end{array}$} & \multirow[t]{2}{*}{$\mathrm{T}$} & \multirow[t]{2}{*}{ Sig. } \\
\hline & & B & Std. Error & & & \\
\hline \multirow[t]{6}{*}{1} & (Constant) & -.170 & .045 & & -3.770 & .000 \\
\hline & Debt to Equity Ratio & .011 & .021 & .029 & .528 & .598 \\
\hline & Price to Book Value & .012 & .005 & .122 & 2.414 & .016 \\
\hline & Net Profit Margin & .023 & .030 & .041 & .783 & .434 \\
\hline & Inflation & .012 & .015 & .039 & .785 & .433 \\
\hline & Tk. Suku Bunga & .023 & .007 & .171 & 3.465 & .001 \\
\hline
\end{tabular}

Source: Primary Data, 2018.

Based on table 1 shows the $\mathrm{X} 1$ variable has a coefficient of 0.011 and a significance value of 0.598 . The variable $\mathrm{X} 1$ has a significance value greater than the confidence level of $0.05(5 \%)$, so it shows that the Debt to Equity Ratio (DER) does not have a significant effect on the Property and Real Estate Sector Stock Returns, thus accepting Ho and rejecting $\mathrm{H} 1$. The results of this study support previous research conducted by Asmi (2014), Kamar (2017), and Sari (2012) which shows that Debt to Equity Ratio (DER) has no significant effect on stock returns.

Based on table 1 shows the variable $X 2$ has a coefficient value of 0.012 and a significance value of 0.016 . The variable $\mathrm{X} 2$ has a significance value smaller than the confidence level of $0.05(5 \%)$, so it shows that Price to Book Value (PBV) has a significant effect on the Property and Real Estate Sector Stock Returns. Coefficient value (+) indicates that PBV has a positive and significant effect on Property and Real Estate Sector Stock Returns, thus rejecting $\mathrm{Ho}$ and receiving $\mathrm{H} 2$. The results of this study support the previous research conducted by Arista and Astohar (2012), Asmi (2014), and Karlina and Widanaputra (2016) which show that Price to Book Value (PBV) has a positive and significant effect on stock returns.

Based on table 1 shows the $\mathrm{X} 3$ variable has a coefficient of 0.023 and a significance value of 0.434 . The variable $\mathrm{X} 3$ has a significance value greater than the confidence level of $0.05(5 \%)$, so it shows that the Net Profit Margin (NPM) does not have a significant effect on the Property and Real Estate Stock Returns, thus accepting Ho and rejecting H3. The results of this study support previous research conducted by Hermawan (2012), and Ginting and Erward (2013) which show that Net Profit Margin (NPM) has no significant effect on stock returns.

Based on table 1 shows the $X 4$ variable has a coefficient of 0.012 and a significance value of 0.433 . The variable $\mathrm{X} 4$ has a significance value greater than the confidence level of $0.05(5 \%)$, so it shows that Inflation has no significant influence on the Property and Real Estate Sector Stock Returns, thus accepting Ho and rejecting H4. The results of this study support previous research conducted by Andes, et.al (2017) and Kirui, et al. (2014), which shows that inflation has no significant effect on stock returns.

Based on table 1 shows the variable $X 5$ has a coefficient value of 0.023 and a significance value of 0.001 . The variable $X 1$ has a significance value smaller than the 
confidence level of $0.05(5 \%)$, so it shows that the interest rate has a significant influence on the stock returns of the Property and Real Estate sectors. Coefficient value $(+)$ indicates that the Interest Rate has a positive and significant influence on the Property and Real Estate Sector Stock Returns, thus accepting Ho and rejecting H5. The results of this study support previous research conducted by Khan and Yousuf (2013) and Karim (2015) which show that the interest rate has a positive and significant effect on stock returns.

The coefficient of determination is the ability of independent variables to contribute to the dependent variable in percentage units.

Table 2 - Adjusted $\left(R^{2}\right)$

\begin{tabular}{|c|c|c|c|c|c|c|c|c|c|}
\hline \multirow[b]{2}{*}{ Model } & \multirow[b]{2}{*}{$\mathrm{R}$} & \multirow[b]{2}{*}{ R Square } & \multirow{2}{*}{$\begin{array}{l}\text { Adjusted } \\
\text { R Square }\end{array}$} & \multirow{2}{*}{$\begin{array}{l}\text { Std. Error } \\
\text { of the Estimate }\end{array}$} & \multicolumn{5}{|c|}{ Change Statistics } \\
\hline & & & & & $\begin{array}{l}\text { R Square } \\
\text { Change }\end{array}$ & F Change & df1 & df2 & Sig. F Change \\
\hline 1 & 0.239 & 0.057 & 0.046 & 0.174775 & 0.057 & 4.964 & 5 & 410 & 0 \\
\hline
\end{tabular}

Source: Primary data, 2018.

Based on Table 2, the test results of the coefficient of determination (adjusted R2) were obtained at 0.057 or $5.7 \%$. These results indicate that the Stock Return is influenced by Debt to Equity Ratio (DER), Price to Book Value (PBV), Net Profit Margin (NPM), Inflation, and Interest Rate of only $5.7 \%$ while the remaining $94.3 \%$ is influenced by factors others that were not examined in this study.

\section{DISCUSSION OF RESULTS}

Factors of the company's financial performance Debt to Equity Ratio (DER) have a positive and insignificant effect on stock returns in the property and real estate sector companies listed on the Indonesia Stock Exchange. This shows that DER does not affect investor decisions in investing. This is based on the idea that there are other factors that can be taken into consideration in addition to the DER factor in making investment decisions.

The company's financial performance factor Price to Book Value (PBV) has a positive and significant effect on stock returns on property and real estate sector companies listed on the Indonesia Stock Exchange. This shows that the higher the value of Price to Book Value (PBV) will have an impact on the greater the level of return (return) of shares that will be received by investors.

Factors of financial performance of Net Profit Margin (NPM) companies have a positive and insignificant effect on stock returns on property and real estate sector companies listed on the Indonesia Stock Exchange. This shows that investors do not pay too much attention to NPM when investing in this sector, because there are other factors such as tax burden that investors need to pay attention to.

Macroeconomic variables Inflation has a positive and insignificant effect on stock returns in the property and real estate sector companies listed on the Indonesia Stock Exchange. This shows that investors believe that the company has a special strategy in dealing with inflation in Indonesia, so that the size of inflation does not affect the return obtained by the company.

Macroeconomic variables on interest rates have a positive and significant effect on stock returns on property and real estate sector companies listed on the Indonesia Stock Exchange. This shows that with the greater SBI interest rate, it will affect the higher stock returns of the property and real estate sectors that investors will get.

\section{CONCLUSION}

This research shows that investors and prospective investors can get the expected stock returns, investors must be able to pay attention to and consider PBV factors and macroeconomic interest rates when making decisions in investing. Further research is expected to add other factors that can affect stock returns such as the Market Value Added 
(MVA), Economic Value Added, and other macroeconomic factors. Research is also expected to extend the research period so that the results obtained are increasingly presenting the real conditions so that information users get more accurate information.

\section{REFERENCES}

1. Andes, Septa L., Zarah Puspitaningtyas \& Aryo Prakoso. 2017. Pengaruh Inflasi, Kurs Rupiah, dan Suku Bunga Terhadap Return Saham Perusahaan Manufaktur. Jurnal Akuntansi Keuangan dan Bisnis, Vol. 10, No.2.

2. Asmi, Tri Laksita. 2014. Current Ratio, Debt to Equity Ratio, Total Asset Turnover, Return on Asset, Price to Book Value Sebagai Faktor Penentu Return Saham. Management Analysis Journal, Vol. 3, No. 2.

3. Ginting, Suriani dan Erward. 2013. Analisis Faktor-Faktor Yang Mempengaruhi Return Saham Pada Perusahaan Manufaktur Yang Terdaftar Di Bursa Efek Indonesia. Jurnal Wira Ekonomi Mikroskil, Vol. 3, No.1.

4. Hawa, Iqomah Bidari. 2017. Pengaruh ROA, DER, NPM, dan EPS Terhadap Harga Saham Pada Perusahaan Properti. Jurnal IImu dan Riset Manajemen, Vol. 6, No. 11. Hermawan, Dedi Aji. 2012. Pengaruh Debt to Equity Ratio, Earning Per Share, dan Profit Margin Terhadap Return Saham. Management Analysis Journal, Vol. 1(5), pp: 1-7.

5. Jogiyanto, H. 2014. Teori Portofolio dan Analisis Investasi. Edisi kesembilan, Yogyakarta, BPFE.

6. Jones, Charles P. 2014. Investment Analysis and Management, $7^{\text {th }}$ Edition. New York: John Wiley \& Sons, Inc.

7. Kamar, Karnawi. 2017. Analysis of The Effect of Return on Equity (ROE) and Debt to Equity Ratio (DER) on Stock Price in Cement Industry Listed in Indonesia Stock Exchange (IDX) in The year 2011-2015. IOSR Journal of Business and Management, Vol. 19(5).

8. Karim, Abdul. 2015. Analisis Pengaruh Faktor Internal dan Eksternal Terhadap Return Saham Perusahaan Manufaktur Yang Terdaftar di Bursa Efek Indonesia (BEI) Periode 2010 - 2012. Media Ekonomi dan Manajemen, Vol. 30 (1), pp. 41-55.

9. Karlina, Ni Wayan Sri dan A.A.G.P.Widanaputra. 2016. Pengaruh Dividen per Share, Return of Equity, dan Price to Book Value Terhadap Return Saham. E-Jurnal Akuntansi Universitas Udayana, Vol.15, No.3.

10. Kasmir. 2017. Analisis Laporan Keuangan. Jakarta: PT Raja Grafindo Indonesia.

11. Khan, Mashrur Mustaque dan Ahmed Sadek Yousuf. 2013. Macroeconomic Forces and Stock Prices: Evidence from the Bangladesh Stock Market, MPRA Paper No. 46528.

12. Kirui, Evans, Nelson H. W. Wawire \& Perez O. Onono. 2014. Macroeconomics Variables, Volatility and Stock Market Returns: A Case of Nairobi Securities Exchange Kenya. International Journal of Economics and Finance, Vol. 6, No.8.

13. Sari L. A. and Hutagaol Y. 2012. Debt to equity ratio, degree of operating leverage stock beta and stock returns of food and beverages companies on the Indonesian stock exchange, Journal of Applied Finance and Accounting, Vol. 2, No. 2, pp. 1-13.

14. Tandelilin, Eduardus. 2010. Analisis Investasi dan Manajemen Portofolio. Edisi Pertama. Yogyakarta, BPFE. 